\title{
Degree of Vaporization in Bipolar and Monopolar Resection
}

Tim Fagerstrom, Claes R Nyman and Robert Hahn

\section{Linköping University Post Print}

N.B.: When citing this work, cite the original article.

Original Publication:

Tim Fagerstrom, Claes R Nyman and Robert Hahn, Degree of Vaporization in Bipolar and Monopolar Resection, 2012, Journal of endourology, (26), 11, 1473-1477.

http://dx.doi.org/10.1089/end.2012.0177

Copyright: Mary Ann Liebert

http://www.liebertpub.com/

Postprint available at: Linköping University Electronic Press

http://urn.kb.se/resolve?urn=urn:nbn:se:liu:diva-86127 


\title{
Degree of Vaporization in Bipolar and Monopolar Resection
}

\author{
Tim Fagerström, M.D., Ph.D., Claes R. Nyman, M.D., Ph.D., and Robert G. Hahn, M.D., Ph.D. ${ }^{2}$
}

\begin{abstract}
Purpose: To compare the in vitro degree of vaporization in bipolar and monopolar resection.

Materials and Methods: Using either a bipolar system or a monopolar system, samples of chicken muscle and lamb kidney were resected in an isolated basin and then desiccated in an incubator. The percentual degree of vaporization for each sample was obtained as a difference between the total fresh weight of the sample and the calculated fresh weights of the resected tissue and remains.

Results: Reference samples showed that the water content was $73 \%$ in muscle and $77 \%$ in kidney. More muscle (mean $52 \%$ ) than kidney $(32 \% ; P<0.0001)$ tissue was vaporized. The fraction of vaporized tissue was significantly higher in the bipolar technique. In muscle, the differences between monopolar and bipolar were $17 \%$ $(P<0.05)$ and $26 \%(P<0.001)$, respectively, depending on the type of irrigation used. For kidney, the differences were $27 \%(P<0.01)$ and $34 \%(P<0.01)$, respectively. Further exploration of the degree of vaporization when using the bipolar resection showed that the choice of loop $(P<0.0001)$, fluid $(P<0.03)$, and tissue $(P<0.0001)$ were all independently associated with the degree of vaporization.

Conclusions: This study indicated that vaporization removes 50\% more tissue than the weight of the resected tissue during conventional tissue resection. Bipolar standard loop resection resulted in a significantly higher degree of vaporization in both muscle and kidney than did monopolar technique. Bipolar resection worked satisfactorily in Ringer's acetate.
\end{abstract}

\section{Introduction}

$\mathbf{T}$

RANSURETHRAl Resection of THE PRostate (TURP) still holds the position as the golden standard treatment for benign prostatic hyperplasia $(\mathrm{BPH})$. An increasing proportion of these operations are now performed with bipolar instruments. With these new instruments, using a bipolar current in ion-containing physiologic saline, the need for a patient grounding plate is no longer necessary. Reasons for the changeover include a more favorable safety profile with respect to blood loss, transfusion rates, fluid absorption, and postoperative recovery. ${ }^{1,2}$

The bipolar loop creates a heated vapor "plasma" pocket that destroys rather than cuts the tissue during movement. The technique also allows the surgeon to perform pure vaporization with the bipolar technique only by changing from loop to button-electrode. ${ }^{3-5}$ This raises the question of whether tissue becomes vaporized also during a regular bipolar TURP. There are anecdotal indices of lower resection weights in bipolar TURP, and there are also studies that show lower resection speed. ${ }^{6}$ This might be explained by a larger fraction of vaporized tissue during bipolar TURP. Because the amount of destroyed tissue is a crucial efficacy parameter, the possibility of an unknown degree of vaporization is an essential issue in any comparison between open surgery and the monoand bipolar resection techniques.

The purpose of the present laboratory study was to investigate the degree to which vaporization occurs when resecting tissue by using the mono- and bipolar techniques. Associated parameters were the size of the electrode and the type of irrigating fluid used.

\section{Materials and Methods}

\section{Materials}

Samples of either chicken muscle or lamb kidney were resected in an isolated plexiglass basin (Fig. 1). The samples were purchased in an ordinary grocery store. Ten samples in each category were resected (Table 1).

\section{Methods}

After weighing on an electronic scale (PB3002-S Delta Range, ${ }^{\circledR}$ Mettler Toledo, Switzerland), the specimen was placed in a plexiglass container filled with $1500 \mathrm{~mL}$ of irrigating fluid at room temperature and fixed to a piece of Styrofoam (Fig. 1). Ten cuts were made in each sample of the 10 study subgroups (Table 1 ).

\footnotetext{
${ }^{1}$ Department of Clinical Science and Education, Karolinska Institutet, Södersjukhuset, Section of Urology, Stockholm, Sweden.

${ }^{2}$ Research Unit, Södertälje Hospital, Södertälje, Sweden, and Faculty of Health Sciences, Linköping University, Linköping, Sweden.
} 


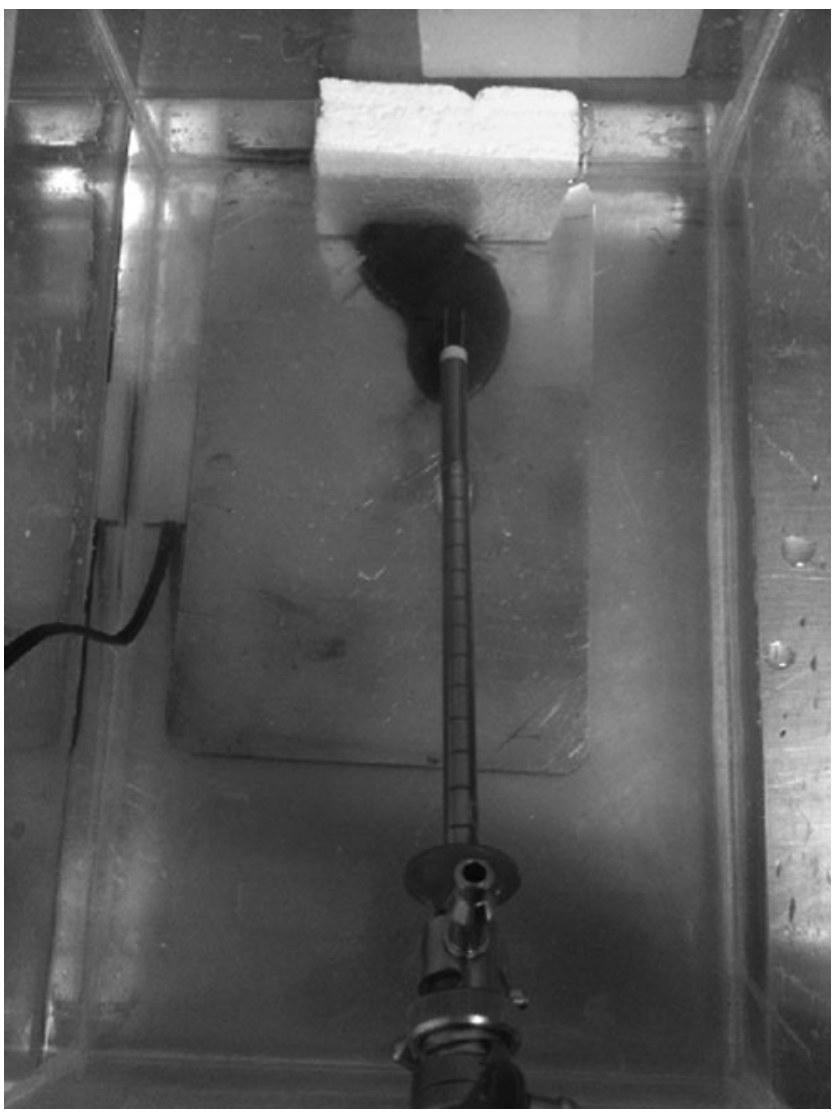

FIG. 1. Arrangement of the in vitro resection.

Bipolar resection was performed with the Olympus transurethral resection in saline system using the Olympus UES 40 generator (Olympus Surgmaster TURis, Tokyo, Japan) either set at $280 \mathrm{~W}(0.2 \mathrm{~mm}, 12$-degree medium loop) or $290 \mathrm{~W}$ (0.2 mm, 12-degree large loop) for cutting. Saline $(0.9 \% \mathrm{NaCl}$, Baxter, Kista, Sweden) and acetated Ringer's solution was used as the irrigant.

Monopolar resection was performed with a Storz 24F resectoscope, using an ERBE ICC 350 generator (Tübingen, Germany) set at $130 \mathrm{~W}$ for cutting. The resections were performed with standard loops and factory-made irrigating fluid that contained mannitol 3\% (Baxter, Kista, Sweden). The neutral electrode was attached to a copper plate of the same size, and the sample was then placed on the plate to obtain a continuous electrical circuit (Fig. 1).

Table 1. Sample Categories*

\begin{tabular}{ll}
\hline Muscle & \multicolumn{1}{c}{ Kidney } \\
\hline $\begin{array}{l}\text { Monopolar: Mannitol, } \\
\text { standard loop }\end{array}$ & $\begin{array}{c}\text { Monopolar: Mannitol, } \\
\text { standard loop }\end{array}$ \\
$\begin{array}{c}\text { Bipolar: Saline, medium loop } \\
\text { Bipolar: Saline, medium loop }\end{array}$ \\
$\begin{array}{c}\text { Bipolar: Saline, large loop } \\
\text { Bipolar: Saline, large loop } \\
\text { medium loop }\end{array}$ & $\begin{array}{c}\text { Bipolar: Ringer acetate, } \\
\text { medium loop }\end{array}$ \\
Bipolar: Ringer acetate, & Bipolar: Ringer acetate, \\
large loop & large loop
\end{tabular}

${ }^{*} \mathrm{~N}=10$ in each category.
After all resections, the removed tissue and remaining piece of tissue were then weighed (wet weight) and heated in an incubator (B8054 Bacterial Chamber, Termaks, Bergen, Norway) at $65^{\circ} \mathrm{C}$ for 72 hours. After complete desiccation, the dry weights were recorded.

Because tissue chips may absorb irrigating fluid, we used reference samples to determine the normal water content of the used tissues. Pieces of unresected chicken and kidney were then desiccated in an incubator for 72 hours in an approximate temperature of $65^{\circ} \mathrm{C}$. During the period in the incubator, the samples were weighed repeatedly until no further weight loss was registered. This yielded the water content if no vaporization occurred. The procedure also provided the time necessary to gain complete desiccation of the samples.

The amount of vaporized tissue was obtained as the difference between the fresh weight of the uncut sample and the sum of the fresh weights (calculated based on its expected "normal" water content) of the resected tissue and the remains.

All the experimental resections were carried out by a consultant urologist with a substantial experience of both methods.

\section{Statistical methods}

All parameters showed a normal distribution. $P<0.05$ was considered significant. Means were compared with independent samples $t$ test. One-way and three-way analysis of variance (ANOVA) analyses of factors important for vaporization were made. Calculations were made in PASW Statistics 18.0.0 (SPSS Inc, Chicago, IL).

\section{Results}

\section{Reference samples}

The water content was $73 \%$ in muscle and $77 \%$ in kidney. This means that $1 \mathrm{~g}$ of fresh sample corresponded to $0.27 \mathrm{~g}$ of dried muscle and $0.23 \mathrm{~g}$ of kidney. These factors were then used throughout the material to convert the total fresh weights into dry weights of the unresected samples (Table 2).

\section{Resected samples}

More muscle (mean 52\%) than kidney $(32 \% ; P<0.0001)$ tissue was vaporized. For both tissues, the fraction of vaporized tissue was significantly higher with the bipolar than with the monopolar instrument. When analyzing the muscle

Table 2. Reference SAmples

\begin{tabular}{lccrcc}
\hline & $\begin{array}{c}\text { Sample } \\
(\#)\end{array}$ & $\begin{array}{c}\text { Fresh } \\
\text { weight } \\
(\mathrm{g})\end{array}$ & $\begin{array}{c}\text { Dry } \\
\text { weight } \\
(\mathrm{g})\end{array}$ & $\begin{array}{c}\text { Desiccated } \\
\text { fraction } \\
(\%)\end{array}$ & $\begin{array}{c}\text { Mean } \\
\text { desiccated } \\
\text { fraction }(\%)\end{array}$ \\
\hline Muscle & 1 & 39.6 & 10.5 & 26.5 & \\
& 2 & 31.9 & 8.7 & 27.3 & \\
& 3 & 34.0 & 9.7 & 28.4 & 27 \\
Kidney & 4 & 21.4 & 5.9 & 27.3 & \\
& 1 & 28.4 & 6.6 & 23.4 & \\
& 2 & 29.6 & 6.5 & 21.9 & 23 \\
& 3 & 28.4 & 6.4 & 22.6 & \\
\hline
\end{tabular}


Table 3. Muscle Vaporization Data

\begin{tabular}{|c|c|c|c|c|c|}
\hline & $\begin{array}{l}\text { Monopolar } \\
\text { standard } \\
\text { loop mannitol }\end{array}$ & $\begin{array}{l}\text { Bipolar } \\
\text { standard } \\
\text { loop saline }\end{array}$ & $\begin{array}{c}\text { Bipolar standard } \\
\text { loop Ringer's } \\
\text { acetate }\end{array}$ & $\begin{array}{l}\text { Bipolar } \\
\text { large } \\
\text { loop saline }\end{array}$ & $\begin{array}{c}\text { Bipolar large } \\
\text { loop Ringer's } \\
\text { acetate }\end{array}$ \\
\hline Fresh weight, uncut sample (g) & $24.9(2.8)$ & $23.7(4.6)$ & $25.3(3.3)$ & $18.1(3.0)$ & $23.9(3.3)$ \\
\hline Fresh weight, remains $(\mathrm{g})$ & $14.8(2.6)$ & $16.6(4.0)$ & $16.6(2.9)$ & $8.9(2.3)$ & $13.2(2.5)$ \\
\hline $\begin{array}{l}\text { Resected weight (backward calculated } \\
\text { into fresh weight) }(\mathrm{g})\end{array}$ & $7.1(1.0)$ & $4.4(0.9)$ & $5.1(1.1)$ & $6.6(1.2)$ & $7.5(1.5)$ \\
\hline $\begin{array}{l}\text { Vaporized total (uncut sample- } \\
\text { remains-resected fresh weight) (g) }\end{array}$ & $3.1(0.6)$ & $2.7(0.8)$ & $3.5(0.6)$ & $2.7(0.3)$ & $3.2(0.4)$ \\
\hline Vaporization/resected tissue $(\%)$ & $45(12)$ & $62^{\mathrm{a}}(18)$ & $71^{\mathrm{b}}(14)$ & $41(6)$ & $43(5)$ \\
\hline
\end{tabular}

Mean (standard deviation). Pairwise significance comparisons $v$ s monopolar technique, ${ }^{\mathrm{a}} P<0.05,{ }^{\mathrm{b}} P<0.001$.

samples, the differences between monopolar and bipolar were $17 \%$ and $26 \%$, respectively, depending on the type of irrigation used (Table 3). For kidney, the differences were $27 \%$ and $34 \%$, respectively (Table 4 ). The degree of vaporization did not differ significantly between the two irrigating fluids used in the bipolar technique, although there was a tendency of a higher degree of vaporization when using Ringer's acetate.

In contrast, bipolar and monopolar resection yielded the same degree of vaporization when using the bipolar large loop instead of the standard loop.

The relationship between wet and dried samples showed that there was a quite consistent uptake of the irrigating fluid by the chips of muscle and kidney amounting to 17 and $12 \%$, respectively, regardless of which type of irrigant was used.

One-way ANOVA showed that the type of loop, the resection method, and the used tissue were factors of importance to the degree of vaporization (Table 5). The choice of irrigant, however, did not affect the vaporization in bipolar resection.

Further exploration of the degree of vaporization when using the bipolar resection instrument was made by threeway ANOVA. This statistical test separates the effects of the three factors on the degree of vaporization from each other, and thereby eliminates confounding intercorrelations between them. Post hoc testing is not needed, because all three factors have only two alternatives.

One single analysis showed that the choice of loop $(P<0.0001)$, fluid $(P<0.03)$, and tissue $(P<0.0001)$ were all independently associated with the degree of vaporization.
In contrast, the choice of loop and the tissue used for cutting did matter much to the amount of tissue that is vaporized.

\section{Discussion}

The results show that vaporization of resected tissue is substantial when using a standard resection system for monopolar and bipolar TURP. Approximately 50\% more tissue disappears than indicated when weighing the amount of resected tissue. This finding is a new knowledge, which also puts the bipolar technique in a new perspective when considering the choice between pure vaporization and conventional resection. One of the conclusions led by this is that a conventional resection not only results in a significantly greater tissue removal than known until now, but also provides a specimen to be analyzed histologically. These facts, in addition to earlier described advantages, put bipolar resection ahead of monopolar technique as well as pure bipolar vaporization and thus the most valuable choice in surgically treating patients with $\mathrm{BPH}$.

The degree of vaporization varies somewhat depending on the type of resected body tissue, the resection technique, and the type of loop used. When resecting $1 \mathrm{~g}$ of muscle, we can expect 1.6 to $1.7 \mathrm{~g}$ of total tissue loss and for kidney, 1.4 to $1.6 \mathrm{~g}$. When performing the same procedure with the bipolar large loop, which resembles the monopolar loop, the degree of vaporization was approximately $45 \%$ for both techniques. The degree of vaporization, however, rose to $60 \%$ to $70 \%$ higher when the bipolar standard loop was used. In contrast, the

Table 4. Kidney Vaporization Data

\begin{tabular}{|c|c|c|c|c|c|}
\hline & $\begin{array}{l}\text { Monopolar } \\
\text { standard } \\
\text { loop mannitol }\end{array}$ & $\begin{array}{l}\text { Bipolar } \\
\text { standard } \\
\text { loop saline }\end{array}$ & $\begin{array}{c}\text { Bipolar standard } \\
\text { loop Ringer's } \\
\text { acetate }\end{array}$ & $\begin{array}{l}\text { Bipolar } \\
\text { large } \\
\text { loop saline }\end{array}$ & $\begin{array}{c}\text { Bipolar large } \\
\text { loop Ringer's } \\
\text { acetate }\end{array}$ \\
\hline Fresh weight, uncut sample (g) & $13.9(3.5)$ & $11.5(2.3)$ & $13.1(2.2)$ & $15.7(2.0)$ & $14.9(2.4)$ \\
\hline Fresh weight, remains $(\mathrm{g})$ & $7.9(2.9)$ & $6.8(2.1)$ & $8.4(2.3)$ & $9.3(2.6)$ & $8.3(1.9)$ \\
\hline $\begin{array}{l}\text { Resected weight (backward calculated } \\
\text { into fresh weight) }(\mathrm{g})\end{array}$ & $5.0(1.3)$ & $3.4(1.6)$ & $3.0(0.5)$ & $5.2(0.9)$ & $5.4(0.9)$ \\
\hline $\begin{array}{l}\text { Vaporized total (uncut sample- } \\
\text { remains-resected fresh weight) (g) }\end{array}$ & $1.1(0.6)$ & $1.3(0.6)$ & $1.7(0.8)$ & $1.2(0.6)$ & $1.2(0.4)$ \\
\hline Vaporization/resected tissue $(\%)$ & $22(12)$ & $39^{a}(15)$ & $56^{\mathrm{a}}(28)$ & $23(10)$ & $22(9)$ \\
\hline
\end{tabular}

Mean (standard deviation). Pairwise significance comparisons vs monopolar technique, ${ }^{\mathrm{a}} P<0.01$. 
Table 5. One-Way Analysis of Variance Analyses of FActors AfFecting VApORization

\begin{tabular}{lccc}
\hline & $n$ & Mean $(S D)$ & $P$ \\
\hline Bipolar Standard loop & 40 & $57(22)$ & $<0.0001$ \\
Bipolar Large loop & 40 & $32(13)$ & \\
Bipolar technique & 80 & $45(22)$ & $<0.031$ \\
Monopolar technique & 20 & $33(17)$ & \\
Muscle & 50 & $52(17)$ & $<0.0001$ \\
Kidney & 50 & $32(21)$ & \\
Saline & 40 & $41(19)$ & 0.15 \\
Ringer's acetate & 40 & $48(24)$ & \\
\hline
\end{tabular}

$\mathrm{SD}=$ standard deviation.

type of irrigating fluid used is of some importance but it is not very great.

These calculations are of importance for comparisons between resection methods and for any judgment of the efficacy of open vs transurethral prostatic surgery. In previous work, we have found that blood loss is significantly lower using the bipolar technique. ${ }^{1}$ Concerning the higher degree of vaporization, this difference is even greater than reported, as further $50 \%$ more tissue is removed when using the bipolar resection instrument as compared with the monopolar. An estimate indicates that the blood loss would then be as low as $6 \mathrm{~mL} / \mathrm{g}$ resected tissue, which is far below any former reported value of TURP-associated bleeding in previous series of both bipolar and monopolar resection. ${ }^{7,8}$

The degree of vaporization in mono- and bipolar TURP has not previously been examined. There is, however, indirect evidence of monopolar vaporization in an earlier study by Sandfeldt and associates. ${ }^{7}$ Here, the signs of vaporization are shown by the difference between preoperative and postoperative transrectal ultrasonography (TRUS) volume, in correlation to the resection weight. In this study, the measurements indicate a vaporization of $35 \%$ to $67 \%$, a figure compromised by the uncertainty of nonplanimetric TRUS assessment, ${ }^{9,10}$ but nevertheless point in the direction of a significant tissue loss that could be explained by vaporization.

The relatively new concept of bipolar TURP has proven advantages. ${ }^{1,2,11,12}$ The bipolar technique is superior in terms of blood loss and reduces-or eliminates-the risk of the classical TUR-syndrome. When assessing the quality of histologic specimens from resected tissue, it has also been shown that the coagulation artefacts of the chips are less than in the ones provided by monopolar resection, thus facilitating a more accurate pathologic diagnosis. ${ }^{13}$ It is also clear that the cautery effect is less pronounced in bipolar technique, which is a benefit in visibility and surgical accuracy for the performing surgeon. ${ }^{14,15}$ The latter is in spite of the fact that the coagulation depth in the residual tissue seems to be deeper than in monopolar resection, ${ }^{16}$ a circumstance that might be the reason for the reduced blood loss in the bipolar technique, although this is not yet fully understood.

The concept of desiccating tissue to decide the true weight of the specimen and the water content has been used in several other studies. ${ }^{17-19}$ Here it was necessary to be sure that absorbed irrigating fluid would not interfere with the calculations of the vaporized tissue. The amount of absorbed fluid, however, was not as unpredictable as first apprehended. The tissue absorbed only about $15 \%$ of its own weight in a quite regular pattern.

When concerning the water content of the two examined kinds of tissues and comparing this with the water content of the human prostate as stated in the study by Leissner and Tisell, ${ }^{18}$ one could assume that the prostate would show approximately the same degree of vaporization as the here examined kidney tissue.

Limitations of the study include that the number of samples was not great, but on the other hand, the results were normally distributed. Another limitation is, of course, that it is not a clear connection between the degree of vaporization of the samples in this study and the one in human prostate tissue, something that needs to be investigated further.

\section{Conclusion}

This laboratory study indicated that vaporization removes $50 \%$ more tissue than the weight of the resected tissue during conventional tissue resection. When using the standard loops, the bipolar resection technique resulted in a significantly higher degree of vaporization in both muscle and kidney than did the monopolar technique. The difference in vaporization was not seen with the bipolar large loop. Bipolar resection worked satisfactorily in Ringer's acetate, although this fluid tended to increase the vaporization.

\section{Disclosure Statement}

No competing financial interests exist.

\section{References}

1. Fagerström T, Nyman CR, Hahn RG. Bipolar transurethral resection of the prostate causes less bleeding than the monopolar technique: A single-centre randomized trial of 202 patients. BJU Int 2010;105:1560-1564.

2. Fagerström T, Nyman CR, Hahn RG. Complications and clinical outcome 18 months after bipolar and monopolar transurethral resection of the prostate. J Endourol 2011;25:1043-1049.

3. Reich O, Schlenker B, Gratzke C, et al. Plasma vaporisation of the prostate: Initial clinical results. Eur Urol 2010;57:693-697.

4. Hon NH, Brathwaite D, Hussain Z, et al. A prospective, randomized trial comparing conventional transurethral prostate resection with PlasmaKinetic vaporization of the prostate: Physiological changes, early complications and long-term followup. J Urol 2006;176:205-209.

5. Tefekli A, Muslumanoglu AY, Baykal M, et al. A hybrid technique using bipolar energy in transurethral prostate surgery: A prospective, randomized comparison. J Urol 2005;174:1339-1343.

6. Rassweiler J, Schulze M, Stock C, et al. Bipolar transurethral resection of the prostate-technical modifications and early clinical experience. Minim Invasive Ther Allied Technol 2007;16:11-21.

7. Sandfeldt L, Bailey DM, Hahn RG. Blood loss during transurethral resection of the prostate after 3 months of treatment with finasteride. Urology 2001;58:972-976.

8. Singh H, Desai MR, Shrivastav P, Vani K. Bipolar versus monopolar transurethral resection of prostate: Randomized controlled study. J Endourol 2005;19:333-338.

9. Tong S, Cardinal HN, McLoughlin RF, et al. Intra- and inter-observer variability and reliability of prostate volume 
measurement via two-dimensional and three-dimensional ultrasound imaging. Ultrasound Med Bio 1998;24:673-681.

10. Acer N, Sofikerim M, Ertekin T, et al. Assessment of in vivo calculation with ultrasonography compared to physical sections in vitro: A stereological study of prostate volumes. Anat Sci Int 2011;86:78-85.

11. Chen Q, Zhang L, Fan QL, Zhou Jet al. Bipolar transurethral resection in saline vs traditional monopolar resection of the prostate: Results of a randomized trial with a 2-year followup. BJU Int 2010;106:1339-1343.

12. Kong $\mathrm{CH}$, Ibrahim $\mathrm{MF}$, Zainuddin $\mathrm{ZM}$. A prospective, randomized clinical trial comparing bipolar plasma kinetic resection of the prostate versus conventional monopolar transurethral resection of the prostate in the treatment of benign prostatic hyperplasia. Ann Saudi Med 2009;29: 429-432.

13. Akgül T, Nuhoğlu B, Polat $\mathrm{O}$, et al. An in vitro study comparing the coagulation and cautery effects of bipolar and unipolar cutting modalities on prostatic tissue. Urol Int 2009;83:458-462.

14. Wendt-Nordahl G, Häcker A, Fastenmeier K, et al. New bipolar resection device for transurethral resection of the prostate: First ex-vivo and in-vivo evaluation. J Endourol 2005;19:1203-1209.

15. Huang $\mathrm{X}$, Wang $\mathrm{XH}, \mathrm{Qu} \mathrm{LJ}$, et al. Bipolar versus monopolar transurethral resection of prostate: Pathologic study in canines. Urology 2007;70:180-184.

16. Huang $\mathrm{X}$, Wang $\mathrm{XH}$, Wang $\mathrm{HP}$, Qu LJ. Comparison of the microvessel diameter of hyperplastic prostate and the coagulation depth achieved with mono- and bipolar transur- ethral resection of the prostate. A pilot study on hemostatic capability. Scand J Urol Nephrol 2008;42:265-268.

17. Reinoso RF, Telfer BA, Rowland M. Tissue water content in rats measured by desiccation. J Pharmacol Toxicol Methods 1997;38:87-92.

18. Leissner KH, Tisell LE. The weight of the human prostate. Scand J Urol Nephrol 1979;13:137-142.

19. Jones AW, Hahn RG, Stalberg HP. Distribution of ethanol and water betwee plasma and whole-blood; inter- and intraindividual variations after administration of ethanol by intravenous infusion. Scand J Clin Lab Invest 1990;50:775-780.

Address correspondence to: Tim Fagerström, M.D., Ph.D. Section of Urology, Södersjukhuset Department of Clinical Science and Education Karolinska Institutet S-118 83 Stockholm Sweden

E-mail: timfagerstrom@hotmail.com

$$
\begin{aligned}
& \text { Abbreviations Used } \\
\text { ANOVA } & =\text { analysis of variance } \\
\text { BPH } & =\text { benign prostatic hyperplasia } \\
\text { TURP } & =\text { transurethral resection of the prostate } \\
\text { TRUS } & =\text { transrectal ultrasonography }
\end{aligned}
$$

